\title{
Plasma Protein Binding of Herbal- Flavonoids to Human Serum Albumin and Their Anti-proliferative Activities
}

\author{
IBRAHIM HALIL GECIBESLER \& MURAT AYDIN
}

\begin{abstract}
Herbal-flavonoids (HF) as polyphenolic secondary metabolites are taken in the daily diet to join in many metabolic processes in the human organism. Anti-proliferative activities and human serum albumin (HSA) binding capacities of herbal-flavonoids namely 7,5'-dimethoxyisoetin (HF1), homoorientin-6"-4-O-methyl-myo-inositol (HF2), $(2 R, 3 R)$-(+)-dihydrokaempferol-7,4'-dimethylether (HF3), eriodictyol-7,4'-dimethylether (HF4) and flavonoids isoorientin (HF5) and genkwanin (HF6) were investigated. Antiproliferative activities were determined by the xCELLigence system by treatment with human prostate (PC3) and cervical cancer (HeLa) cells. The binding capacities were studied by two-dimensional (2D-FL) and three-dimensional (3D-FL) fluorescence spectroscopy. HeLa and PC3 cell lines were treated with flavonoids at 10, 50 and 100 $\mu \mathrm{g} / \mathrm{mL}$ concentrations over a 48 hour period. Stable anti-proliferative efficacy plots were obtained for tested flavonoids. From the flavonoids, HF3 and HF4 showed the strongest anti-proliferative effect against PC3 and HeLa cell line. HF1 and HF2 exhibited the strongest binding capacity to the HSA corresponding to $K_{b}$ values of $3.81 \times 10^{4} \mathrm{M}^{-1}$ and $6.00 \times 10^{4} \mathrm{M}^{-1}$, respectively. The studies revealed that the flavonoids form the basis of in vivo preclinical studies as important nutraceuticals of the daily diet, as well as modelled in medical and pharmacological applications.
\end{abstract}

Key words: Herbal-flavonoids, HSA, PC3, HeLa, xCELLigence, 3D-FL.

\section{INTRODUCTION}

Flavonoids are bioactive secondary metabolites occurring in higherplants. They have broadspectrum pharmacological effects including anticancer, antioxidant, antimicrobial, anti-inflammatory, anti-allergic and immunosuppressive, as well as low systemic toxicity. Also, they have important physiological effects such as binding to human serum albumin protein (Poor et al. 2012, Vanekova et al. 2019, Pawar et al. 2019, Gecibesler \& Erdogan 2019, Gecibesler et al. 2019), inhibition and transport of different specific enzymes (Havsteen 2002).
Furthermore, some flavonoids exhibit blood thinner and antiplatelet activity (Guglielmone et al. 2002, Khan et al. 2018, Bijak et al. 2019).

Human serum albumin (HSA) is the most abundant carrier protein (about $46 \mathrm{mg} / \mathrm{mL}$ ) in blood plasma (Basken \& Green 2009, Callmann et al. 2019). It is also responsible for the transport of endogenous and exogenous substances such as fatty acids, amino acids, hormones, ions and medicines (Cui et al. 2010, Naik et al. 2010, Yaseen et al. 2018, Pang et al. 2019). HSA, a globular protein, has three domains (I, II and III). Each domain is divided into two sub-domains of $A$ and $B$, respectively (IA, IB, IIA, IIB, IIIA and IIIB). 
These sub-domains are interconnected by crosslinked disulfide bridges. There are 17 disulfide bridges in total, one free thiol (Cys-34) and one tryptophan (Trp-214) in the amino acid sequence of HSA (Bian et al. 2004). Each region of HSA has its own specific binding property (Narazaki et al. 1997, Sen et al. 2009, Mohan et al. 2018). Studies on the binding of aglycone flavonoids to the sub-domain IIA of the HSA protein have been published by several research groups (Kanakis et al. 2006, Bolli et al. 2010, Di Bari et al. 2010, Rimac et al. 2017, Wang et al. 2018). The presence of such multiple binding sites of HSA ensures that interaction with many organic and inorganic molecules plays an important role in the intracellular fluxes regulator and the pharmacokinetic behavior of many drugs, as well as its unusual binding ability.

Bioactive flavonoids interact with proteins and enzymes to prevent the emergence of pathological conditions. Moreover, these flavonoids are taken from natural products such as fruits, vegetables and medicinal herbs for nutraceutical purposes on a daily diet. In previous studies, it was shown that performing biological activity studies of isolated plantbased natural flavonoids are crucial for the discovery of new and effective drugs (Liu et al. 2015, Badr et al. 2016, Gecibesler et al. 2017, Gecibesler 2019).

Anti-proliferative activities of flavonoids 7,5'-dimethoxyisoetin (HF1), homoorientin6"-4-O-methyl-myo-inositol (HF2), (2R,3R)-(+)dihydrokaempferol-7,4'-dimethylether (HF3) and eriodictyol-7,4'-dimethylether (HF4) against HeLa and PC3 cells and binding capacities to HSA have not been investigated. Interactions of target flavonoids with HSA protein were performed by 2D-FL and 3D-FL fluorescence spectroscopy and anti-proliferative activities against HeLa and PC3 screened by xCELLigence RTCA SP system. The most potent binding capacity to HSA was determined as flavonoids HF1 $\left(3.81 \times 10^{4} \mathrm{M}^{-1}\right)$ and HF2 $\left(6.00 \times 10^{4} \mathrm{M}^{-1}\right)$. Determination of the fluorescence parameters of the target flavonoids is a crucial tool for understanding the functions, structures, dynamics and interactions of macromolecules such as proteins and enzymes in biological systems. In the anti-proliferative activity tests, the HF3 and HF4 produced stable decreasing proliferation curves for HeLa and PC3 cell line at concentrations of 10,50 , and 100 $\mu \mathrm{g} / \mathrm{mL}$.

\section{MATERIALS AND METHODS}

\section{Reagents}

Test compounds namely 7,5'-dimethoxyisoetin (HF1), homoorientin-6"-4-O-methyl-myoinositol (HF2), (2R,3R)-(+)-dihydrokaempferol7,4'-dimethylether (HF3), eriodictyol-7, $4^{\prime}$ dimethylether (HF4), isoorientin (HF5) and genkwanin (HF6) were isolated from endemic Phyrna ortegioides by chromatographic techniques and their chemical structures were determined by spectroscopic techniques. (Figure 1). All of the flavonoids were isolated from $P$. ortegioides for the first time and compounds HF1 and HF2 were reported as novel compounds (Gecibesler et al. 2017). Sodium hydroxide, formic acid, ethanol, human serum albumin (HSA), fetal bovine serum (FBS), phosphate buffered saline (PBS) penicillin-streptomycin, sterile dimethyl sulfoxide (DMSO), Dulbecco's Modified Eagle's Medium, high glucose (DMEM) was obtained from Merck and Sigma Aldrich.

\section{Cell culture}

HeLa and PC3 cell lines were provided by Istanbul University Faculty of Pharmacy. The cells were originally purchased from the American Type Culture Collection. The medium was prepared by adding penicillin-streptomycin (2\%) to DMEM + FBS (10\%) mixture. The prepared medium was 
taken into $50 \mathrm{~mL}$ falcon tubes and stored at $+4^{\circ} \mathrm{C}$. The cell lines were reproduced from previous strains which were stocked at $-80^{\circ} \mathrm{C}$. Cell lines at $-80^{\circ} \mathrm{C}$ were brought and thawed rapidly at $37^{\circ} \mathrm{C}$ and the prepared medium was added and centrifuged. After the supernatant was removed, the remaining pellet was mixed with the medium and transferred to cell seeding flasks. Cell seeding flasks were placed in an incubator containing $5 \% \mathrm{CO}_{2}$ at $37^{\circ} \mathrm{C}$. For the growth of the cells, the final volume of flasks was completed with DMEM medium containing L-glutamine + FBS $(10 \%)$ to $15 \mathrm{~mL}$. Passaging process of the cells was carried out after the cells covered a certain surface area of the flask (about 90\%) and the medium in the flask was removed cells were washed twice with sterile PBS. After washing, PBS was removed. The trypsinization was performed using trypsin EDTA to detach cells from the flask.

\section{Test compound solutions}

Flavonoids were dissolved in DMSO and diluted to desired concentrations with DMEM for antiproliferative activity tests. The control wells received the same amount of DMSO with test wells $(0.001 \%$ in the highest concentration). In all experiments, the DMSO concentration was below $1 \%$. For the fluorimetric measurements, the flavonoids were dissolved in ethanol and pipetted into glass flasks. Ethanol was removed in a nitrogen gas atmosphere.

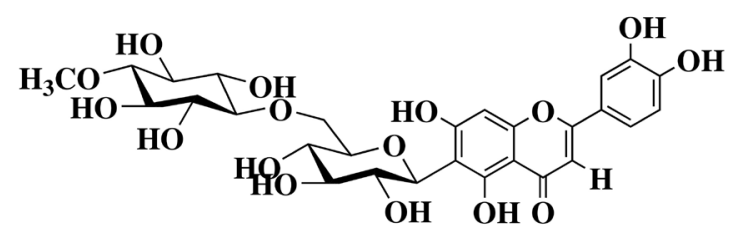

Homoorientin-6"-4-O-methyl-myo-inositol (HF2)

7,5'-dimethoxyisoetin (HF1)<smiles>COc1ccc([C@H]2Oc3cc(OC)cc(O)c3C(=O)[C@H]2O)cc1</smiles>

(2R,3R)-(+)-dihydrokaempferol-7,4'-dimethylether (HF3)<smiles>O=c1cc(-c2ccc(O)c(O)c2)oc2cc(O)c(C3OC(O)C(O)C(O)C3O)c(O)c12</smiles>

Isoorientin (HF5)<smiles>COc1cc(O)c2c(c1)O[C@@H](c1ccc(OC)c(O)c1)CC2=O</smiles>

Eriodictyol-7,4'-dimethylether (HF4)<smiles>COc1cc(O)c2c(=O)cc(-c3ccc(O)cc3)oc2c1</smiles>

Figure 1. The chemical structures of flavonoids (HF1-6). 


\section{xCELLigence RTCA SP System}

Proliferation experiments were performed using an xCELLigence RTCA SP (ACEABIO, USA) System with an incubator capable of producing moisture at $37^{\circ} \mathrm{C}$ and $5 \% \mathrm{CO}_{2}$ (Abay et al. 2015, Oke Altuntas et al. 2016). The system allows observation of the anatomical and morphological states of the cells added to the wells via microelectrodes located at the bottom of the E-plate 96 wells. Proliferation experiments were performed in three steps. First, the medium ( $50 \mu \mathrm{L})$ was added to each well of the E-plate 96 to allow thermal equilibration for 15 minutes in the incubator. At the end of the incubation period, the impedance measurement was recorded by placing the plate in the XCELLigence SP station for $1 \mathrm{~min}$. Second, the cell suspension $(25.000$ cells $/ 100 \mu \mathrm{L}$ ) was added to each of the wells by removing the E-plate 96 from the station. The plate was left in the sterile cabin for 30 minutes to allow the cells to adhere to the microelectrode on the bottom surface the E-plate-96 wells. At the end of the waiting period, E-plate 96 was placed in the RTCA station and performed the second measurement for $80 \mathrm{~min}$. During the second step, the states of the cells were monitored via microelectrodes. Flavonoids were dissolved in sterile DMSO $(20 \mathrm{mg} / \mathrm{mL})$ and diluted with DMEM $(10,50$ and $100 \mu \mathrm{g} / \mathrm{mL})$. At the end of the second step, the compounds prepared at different concentrations were added to the wells but not added to the control and medium wells. The final volumes of the wells were adjusted to $200 \mu \mathrm{L}$ with the medium. All measurements were performed in three replicates. Finally, after addition of the flavonoids, the measurements were made by placing them in the E-plate 96 xCELLigence RTCA SP station. In the last step, the status of the cells was monitored every 10 minutes for 48 hours. The percentage of cell index loss over a given time interval was calculated using the following equation $[\% \mathrm{LCl}=$
$(\mathrm{CCl}-\mathrm{ECl} / \mathrm{CCl}) \times 100]$. The equation shows the $\mathrm{LCl}$ percentage of cell index loss, the $\mathrm{Cl}$ control cell index, and the $\mathrm{ECl}$ experimental cell index.

\section{Fluorescence spectroscopy}

2D-FL and 3D-FL measurements of flavonoidHSA interactions were qualitatively and quantitatively analyzed using a Perkin-Elmer (Model LS 55) spectrophotometer (Namiesnik et al. 2014). The pH for the flavonoid-HSA interaction was adjusted to 7.2 in a phosphate buffer of $5 \mu \mathrm{M}$ as the concentration of the HSA solution. The emission wavelength ranges for the 2D-FL measurements were selected to be 285$500 \mathrm{~nm}$, and the excitation wavelength $280 \mathrm{~nm}$. The excitation and emission slit spacing was set to $5 \mathrm{~nm}$ and the scan speed to $1000 \mathrm{~nm} / \mathrm{min}$. For 3D-FL measurements, the emission wavelength range was 220-450 $\mathrm{nm}$. The excitation wavelength was adjusted to $210 \mathrm{~nm}$ and to reach $450 \mathrm{~nm}$ with an increase of $8 \mathrm{~nm}$ was performed in a total of 25 scans. The excitation and emission slit spacing was set to $5 \mathrm{~nm}$ and the scan speed to $1000 \mathrm{~nm} / \mathrm{min}$. Optimum concentration ranges for flavonoid compounds were determined to prevent aggregation (Salci \& Toprak 2017).

\section{Interaction constant $\left(\boldsymbol{K}_{\mathrm{sv}}\right)$}

The following Stern-Volmer equation was used to calculate the interaction constant between HSA and flavonoids. The substances that reduce the fluorescence intensity of fluorophores are called quencher.

$$
\frac{F_{0}}{F}=1+K_{S V}[Q]
$$

In the equation, $F_{0}$ is the fluorescence intensity of fluorophore in the absence of quencher, $F$ is the fluorescence intensity of fluorophore in the presence quencher, [Q] is the flavonoid concentration of added to the reaction medium as a quencher, $K_{S V}$ is Sternvolmer quenching constant. 


\section{Binding constant $\left(K_{b}\right)$}

Quenching ability of a molecule, either by complex formation or establishing interaction in a quenching event, is evaluated by calculating the binding constant of this molecule by the following formula:

$$
\log \left(\frac{F_{0}-F}{F}\right)=\log K_{b}+n \log [Q]
$$

Here, $K_{b}$ is binding constant, $n$ is the number of connecting/interacting side, $Q$ is the concentration of the quencher, $F_{0}$ is fluorescence intensity and $F$ is fluorescence intensity in the presence of a quencher (Wang et al. 2006).

\section{Statistical analysis}

Analysis results expressed as mean \pm standard deviation $(n=3)$. Statistical differences were performed with SPSS 21 software using one-way analysis of variance (Tukey and Duncan). The error bars represent the standard deviation of the experimental results.

\section{RESULTS AND DISCUSSION}

\section{Anti-proliferative activities}

The xCELLigence real-time graphs obtained in the treatment of HeLa and PC3 cells with the flavonoids cells are shown in the Figure $2 \mathrm{a}$. Proliferation plots of flavonoids against PC3 and HeLa cells were obtained as a result of real-time monitoring during 48-hour. Flavonoids showed significant anti-proliferative activities against both HeLa (human cervical carcinoma) and PC3 (human prostate cancer) cells at 10, 50 and 100 $\mu \mathrm{g} / \mathrm{mL}$ concentrations. The flavonoids (HF1-6) caused the loss of cell index ( $\mathrm{LCl}$ ) in a dosedependent manner as measured by real-time impedance analysis on both the PC3 and the HeLa cells (Figure 2a). The $\mathrm{LCl}$ values at 36 hours at different concentrations of compounds are given in Figure $2 \mathrm{~b}$. The $\mathrm{LCls}$ of the compounds on concentration-dependent cell lines at 36 hours were statistically significant at $p<0.05,<0.01$ and $<0.001$. The $\mathrm{LCls}$ at the concentrations of 10 and $50 \mu \mathrm{g} / \mathrm{mL}$ of the HF1 on the PC3 cells was 3.47 and $17.69 \%$, respectively $(p<0.05$ and $<0.01$ ). The LCls of the PC3 cells at concentrations of 50 and $100 \mu \mathrm{g} / \mathrm{mL}$ of the HF4 were 15.6 and $52.7 \%$, respectively $(p<0.05,<0.01$ and $<0.001)$, while of the HeLa cells at the same concentrations were 0.58 and $35.1 \%$, respectively $(p<0.05$ and $<0.01)$. The LCls at concentrations of 10 and $50 \mu \mathrm{g} / \mathrm{mL}$ of the HF3 on the PC3 cells were found to be 9.75 and $30.51 \%$, respectively $(p<0.05,<0.01$ and $<0.001$ ). However, the LCls at 50 and $100 \mu \mathrm{g} / \mathrm{mL}$ concentrations of the HF3 on the HeLa cells were found to be 10.63 and $25.73 \%$, respectively $(p<0.05,<0.01$ and $<0.001)$.

The difference in the antiproliferative activities of flavonoids against PC3 and HeLa cells is due to the differences in structural properties of these compounds, in particular, the regulation of hydroxyl, methoxy and other functional groups substituted to the flavonoid skeleton which determines their proliferation inhibitory effects (Kanadaswami et al. 2005). Also, Pouget et al. (2001) reported the antiproliferative effects of these functional substituents on different positions in the flavonoid skeleton (Pouget et al. 2001). Another research group proved that double bond (at C2-C3 position in the pyran ring), ortho-catechol group (in the $\mathrm{B}$ ring) and hydroxyl group (at C3 position in the pyran ring) were important for anti-proliferative activity (Kawaii et al. 1999). Furthermore, the cytotoxicities of flavonoid are assumed to be related to the position and number of hydroxyl groups (Kilani-Jaziri et al. 2012). On the other hand, unsubstituted flavonoids with functional groups and monohydroxylated flavones have low anticancer activity, whereas some dihydroxyflavones have been reported to exhibit high anticancer activity. 

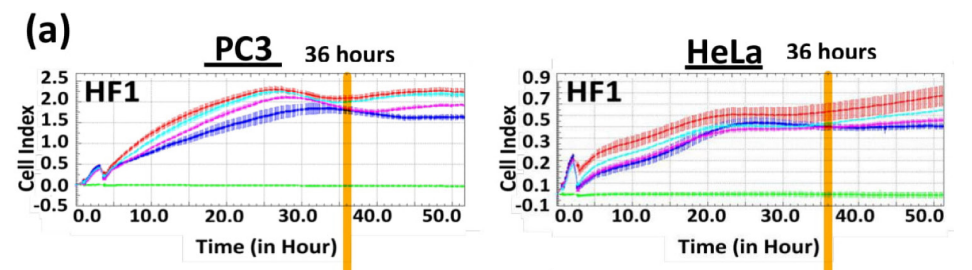

Figure 2. The anti-proliferative activities of flavonoids (HF1-6) against PC3 (human prostate cancer) and HeLa (human cervical cancer ) cell lines $(-100 \mu \mathrm{g} / \mathrm{mL},-50 \mu \mathrm{g} /$ $\mathrm{mL},{ }^{-} 10 \mu \mathrm{g} / \mathrm{mL},-$ Control, - Medium) 7,5'-dimethoxyisoetin (HF1), homoorientin6"-4-O-methyl-myo-inositol (HF2), (2R, 3R)
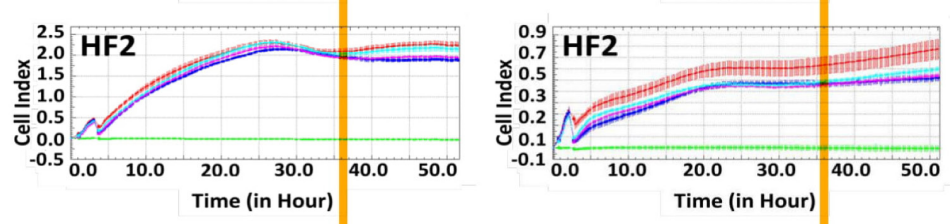
-(+)-dihydrokaempferol-7,4'-dimethylether (HF3), eriodictyol-7,4'-dimethylether (HF4), isoorientin (HF5) and genkwanin (HF6) Cell lines $\left(2.5 \times 10^{4}\right.$ cells/well) were plated to each well of the E-plate 96 and achieved to gain
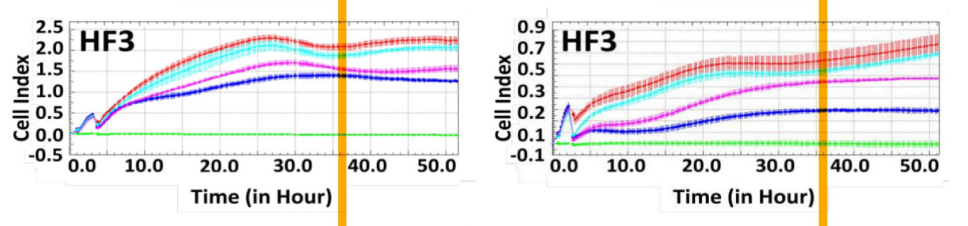
impedance $80 \mathrm{~min}$ prior to the addition of flavonoids at different concentrations. Cell index plots were given in (a) for 48 hours. Percent loss of cell index quantified in (b) after 36 hours Results were expressed as
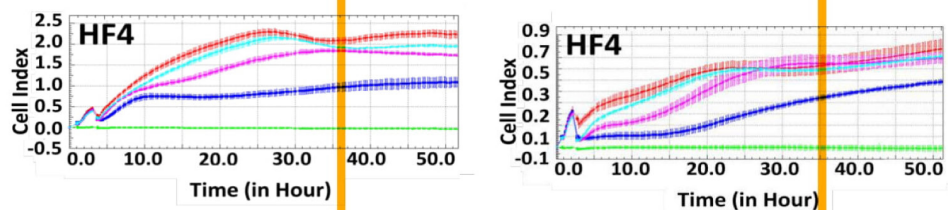
mean \pm standard deviation $(n=3) . *, p<0.05$ and $0.01{ }^{* *}, p<0.001$; Tukey and Duncan.
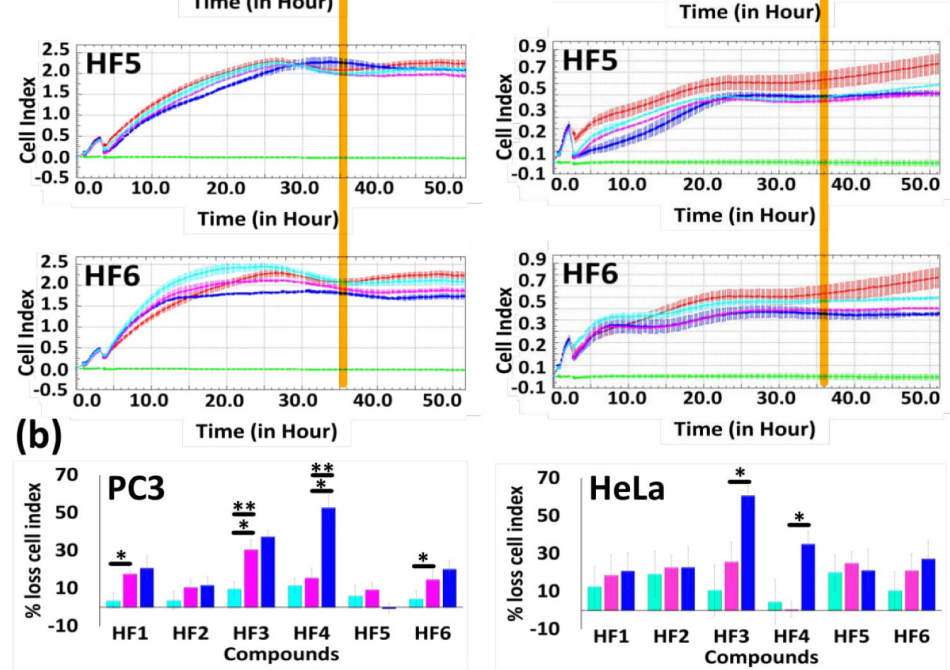

The structure activity relationship (SAR) was revealed by comparing the proliferation inhibiting activities of the tested flavonoids, i.e., 7,5'-dimethoxyisoetin (HF1), homoorientin6"-4-O-methyl-myo-inositol (HF2), (2R,3R)-(+)dihydrokaempferol-7,4'-dimethylether (HF3), eriodictyol-7,4'-dimethylether (HF4), isoorientin (HF5) and genkwanin (HF6) on the HeLa and PC3 cells. In particular, HF3 and HF4 showed relatively higher antiproliferative activities than the others due to the presence of methoxy and the single bond (at C2-C3 position in the pyran ring). On the other hand, this study showed that flavonoid-O-glycosides such as HF2 and HF5, the sugar part of the structure, had a less significant effect on inhibition of both cell lines so that 6-O-glycosylation in flavonoids HF2 and HF5 was not necessary for antiproliferative activity. These results appear to be more important for the inhibitory potential with which functional group the flavonoid skeleton is substituted (Das et al. 2014). Similarly, the accuracy of this result 
has been reported by different researchers that flavone glycosides are not effective against cancer cell lines (Martens \& Mithöfer 2005, Tapas et al. 2008, Pinheiro \& Justino 2012, Choi et al. 2012). Regarding the inhibition of PC3 and HeLa cell lines treated by flavonoids HF3 and HF4, both have proved to be important that O-methylated and containing single bond (at C2-C3 position in the pyran ring) play important roles. These results are consistent with other reported results (Bandgar et al. 2010, Bahmani et al. 2017, Grigalius \& Petrikaite 2017). Furthermore, this study demonstrates that the presence of the sugar groups and hydroxyl groups of the compounds HF1, HF2, HF5 and HF6 in the flavonoid structure is insignificant for increasing in vitro inhibitory activity. This study also showed that HF3 and HF4 compounds had the most important effect on inhibition of proliferation in PC3 and HeLa cell lines, indicating that the presence of multiple methyl ester and the presence of single bond (at C2-C3 position in the pyran ring) together in the compounds greatly affected their activity.

Pouget et al. (2001) reported a study demonstrating a structure-activity relationship that supports our study. In their study, they reported that the presence of methoxyl groups in flavonoid skeleton increased antiproliferative activity against tumour cells, greatly reducing the effects of substitution with hydroxyl groups (Pouget et al. 2001). Our results showed that better effects can be achieved by substitution of methoxyl groups in the flavonoid skeleton at C7 and C4'. Similarly, Walle et al. (2007) showed a promising antiproliferative agent of dimethoxyflavonoids, which differ from the flavonoids that are substituted with hydroxyl groups (Walle et al. 2007). In a deeper study, methoxyflavonoids were eight times more effective than their hydroxylated analogues. In addition, many studies have proved that methoxyflavonoids are remarkable because these compounds have higher oral bioavailability compared to hydroxylated flavones (Walle 2007, Walle et al. 2007, Seito et al. 2011).

When the studies on the structure-activity relationship of methoxyflavonoids are examined, it is worth to note that methoxy groups in the flavonoid skeleton show antiproliferative activity with low toxicity. (Pouget et al. 2001, Li et al. 2006, 2007, Du \& Chen 2010, Wongsrikaew et al. 2011, 2012).

From, fruit, herb and vegetable natural flavonoids such as apigenin, luteolin, quercetin, naringenin and epigallocatechin have been reported to play an important role in the prevention of cancer and reports have shown that the flavonoids can be inhibited by cancer cells through different biochemical mechanisms (Zenget al. 2014, Raha et al. 2015, Erdogan et al. 2016, Lin et al. 2017).

Thus far, it has not been reported that the anti-proliferative activities of selected flavonoid compounds, including 7,5'-dimethoxyisoetin (HF1), homoorientin-6"-4-O-methyl-myoinositol (HF2), (2R,3R)-(+)-dihydrokaempferol7,4'-dimethylether (HF3) and eriodictyol-7,4'dimethylether (HF4), against PC3 and HeLa cancer cell lines. In literature, there is a very limited number of anti-proliferative studies on isoorientin (HF5) against PC3 and HeLa cell lines (Karakaya et al. 2017). Similarly, there is only a limited number of anti-proliferative studies on the genkwanin (HF6) against the HeLa cancer cell line (Awouafack et al. 2016, Hong et al. 2017).

Although the newly developed synthetic anticancer agents are clinically successful, there are certain limitations, such as high peripheral neurotoxicity, complex synthesis procedures, and drug resistance from many drug-resistant carriers. Therefore, effective, inexpensive and new anti-proliferative agents for the treatment of different types of cancer from natural sources 
has become the focus of new drug discovery (Demirtas et al. 2013, Wang et al. 2014).

Flavonoids taken in the daily diet, antiproliferative drug candidates, in addition to anti-proliferative health benefits have the importance of multi-faceted health benefits such as cardiovascular disease protection (Wang et al. 2014), weight management (Tominaga et al. 2006), prevention of age-related neurodegenerative diseases (Beking \& Vieira 2010), viral and bacterial infection (Boubakeur et al. 2015), vascular fragility (Terao 2017), allergy (Castell et al. 2014), anti-platelet aggregation effects (Faggio et al. 2017), anti-inflammatory activity (Marzocchella et al. 2011), antioxidant activity (Pal \& Verma 2013, Gecibesler et al. 2016), and ion transfer effects (Trischitta \& Faggio 2006). Furthermore, some flavonoids taken in the diet had protective effects against the risk of smoking-related cancer (Woo \& Kim 2013). In addition to flavonoids could function as chemopreventive agents that interfered with many cancer mechanisms by preventing induction and differentiation of apoptosis (Menezes et al. 2016). Also, a high intake of fresh fruits and vegetables rich in flavonoids has been reported to provide cancer protection against many common human cancers such as lung, breast, prostate, and colon (Pathak et al. 2014).

Some examples of the above-mentioned natural flavonoids that show anti-proliferative activity and emphasize their potential for the development of new chemotherapeutic agents. Therefore, 7,5'-dimethoxyisoetin (HF1) and homoorientin-6"-4-O-methyl-myo-inositol (HF2) and other known flavonoids, which are isolated from $P$. ortegiodes and newly introduced into the literature, can be shown as new anti-proliferative agent candidates after further investigation of the mechanisms of biomolecular action.

\section{Binding capacities}

Fluorescence spectrometry is a fast, easy, and highly reproducible method of describing the interaction of serum albumin, which forms a large part of plasma proteins, with bioactive molecules. The decrease in the fluorescence intensity (FI) of fluorophore such as tryptophan provides useful information about the interaction and binding type of these bioactive molecules with the albumin molecules. In this context, the interactions of HSA protein with flavonoids and the fluorescence changes of albumin were studied by two- and threedimensional fluorescence spectrometry. As a result of the studies, it was obvious that the $\mathrm{FI}$ of HSA decreased gradually with the increase in the concentration of flavonoid in a constant concentration of HSA. This decrease in the FI of HSA indicates that flavonoids interact with HSA.

Interactions of the flavonoids with the HSA were chosen between the optimum concentration ranges and the emission wavelength (EM) range of 285-500 $\mathrm{nm}$. The binding capacities of the HSA to each flavonoid were determined qualitatively and quantitatively considering the decrease in the FI of HSA. HSA solution was used at a constant concentration of $330 \mu \mathrm{g} / \mathrm{mL}$ in 2D-FL and $3 \mathrm{D}-\mathrm{FL}$ fluorescence spectra. The concentration of each flavonoid has been optimized so as not to cause aggregation with HSA. All 3D-FL spectral studies were recorded at EM of $220-450 \mathrm{~nm}$ and the excitation wavelength (EX) range at 205-402 nm.

In 2D-FL spectroscopy studies, the FI value at the EM of $346.5 \mathrm{~nm}$ for the HF1 $(1.25 \mu \mathrm{g} / \mathrm{mL})$ + HSA system was 211.8 while at the same EM, HF1 $(10 \mu \mathrm{g} / \mathrm{mL})+$ HSA system decreased the FI value to 30.2. The Fls at the lowest and highest concentrations of the HF1 molecule show that the HF1 significantly interacts with the fluorophore groups in the HSA present in the medium compared to the FI value (357.4) of the HSA (Figure 3). 

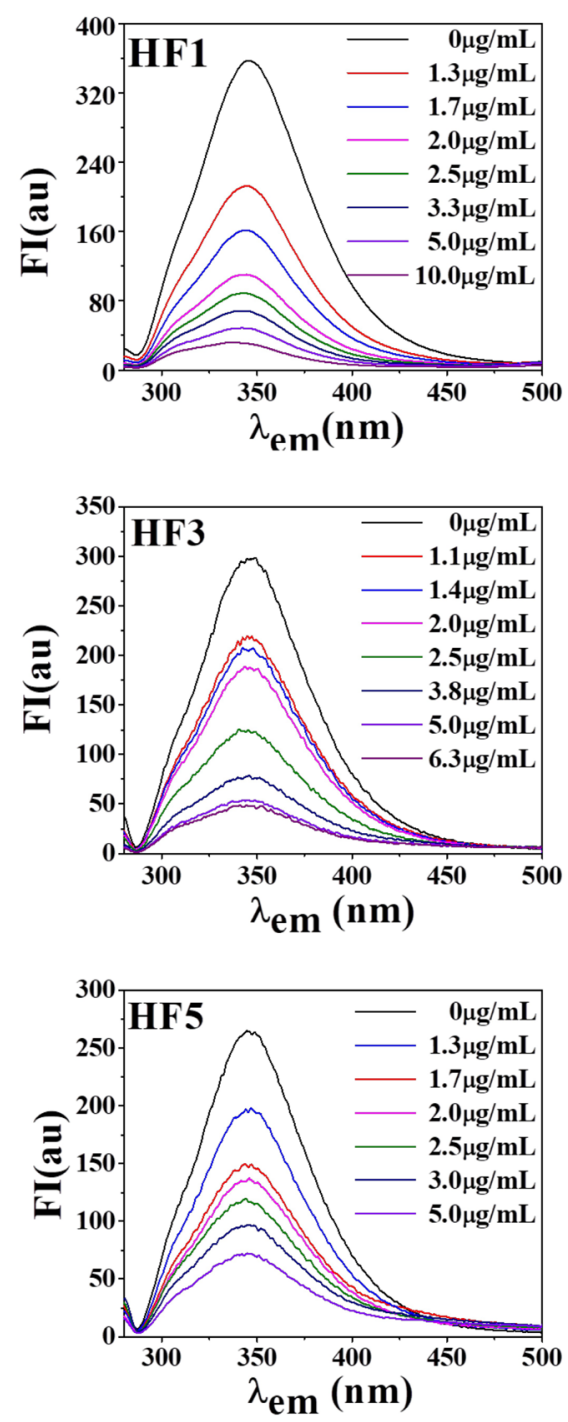

The 3D-FL and 3D map surface spectra were picturized that the $\mathrm{Fl}$ for the HF1 $(5 \mu \mathrm{g} / \mathrm{mL})+$ HSA system was measured as 42.4 and at this FI the EX and the EM were recorded at $275 \mathrm{~nm}$ and $344 \mathrm{~nm}$, respectively $\left(\lambda_{\mathrm{ex}} / \lambda_{\mathrm{em}}: 275 / 344\right)$ (Figure 4). The FI values of the HSA and the HF2 at different concentrations $(0.63-2.5 \mu \mathrm{g} / \mathrm{mL})$ ranged from 38.6 to 196.9 at the EM of $345.5 \mathrm{~nm}$ was recorded. The FI was 54.1 in 3D-FL and 3D map surface spectra for the HF2 $(1.7 \mu \mathrm{g} / \mathrm{mL})+$ HSA system. The $\lambda_{\mathrm{ex}} / \lambda_{\mathrm{em}}$ values were measured as a 279/349 (Figure 4). When figure 3 is examined, it can be seen that the $\mathrm{FI}$ of HSA decreased gradually with the increase in the concentration of the HF3. The FI in 3D-FL
Figure 3. The twodimensional fluorescence spectra (2D-FL) of flavonoids 7,5'-dimethoxyisoetin (HF1), homoorientin6"-4-O-methyl-myoinositol (HF2), (2R,3R)(+)-dihydrokaempferol7,4'-dimethylether (HF3), eriodictyol-7,4'dimethylether (HF4) flavonoids isoorientin (HF5) and genkwanin (HF6). The spectra of the flavonoidHSA interactions were obtained using the optimum experimental conditions including HSA concentration was $5.0 \mu \mathrm{M}$, emission wavelengths from 285 to 500 $\mathrm{nm}, \mathrm{pH} 7.2$, temperature 298 $\mathrm{K}$ and excitation wavelength $280 \mathrm{~nm}$.

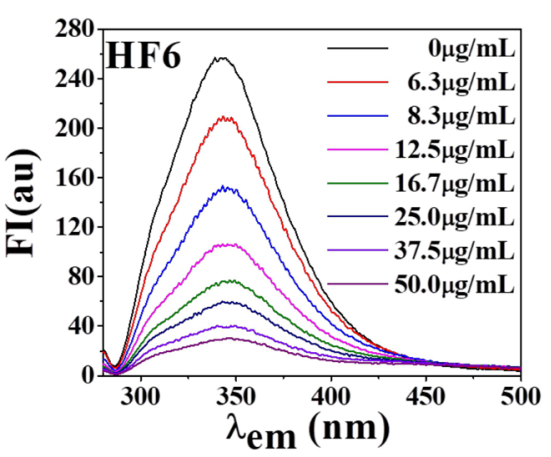

and 3D map surface spectra for HF3 $(5 \mu \mathrm{g} / \mathrm{mL})$ + HSA system was 146.4, and $\lambda_{\mathrm{ex}} / \lambda_{\mathrm{em}}$ values were 273/345 (Figure 4). The FI in 3D-FL and 3D map surface spectra for HF4 $(3.8 \mu \mathrm{g} / \mathrm{mL})+$ HSA system was measured as 178.2 and, $\lambda_{\text {ex }} / \lambda_{\text {em }}$ values were 273/344 (Figure 4). The FI value was measured as 22.9 at the EM of $346 \mathrm{~nm}$ for the system of HF4 $(5 \mu \mathrm{g} / \mathrm{mL})+\mathrm{HSA}$. Significant decreases in the $\mathrm{Fl}$ values were observed with increasing concentrations of HF5 for HSA + HF5 systems. For example, the FI for the HF5 $(5 \mu \mathrm{g} / \mathrm{mL})+\mathrm{HSA}$ system was 71.8, and the EM was measured as $346 \mathrm{~nm}$ (Figure 4). The HF6 was able to interact with HSA at very high concentrations $(6.3-50 \mu \mathrm{g} /$ 
3D-FL
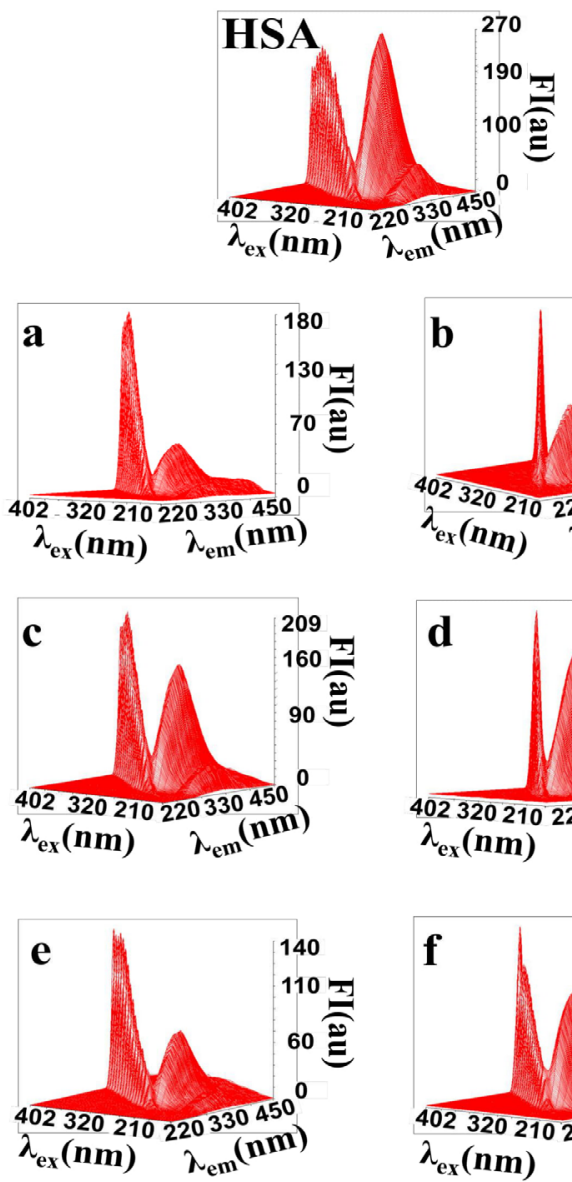
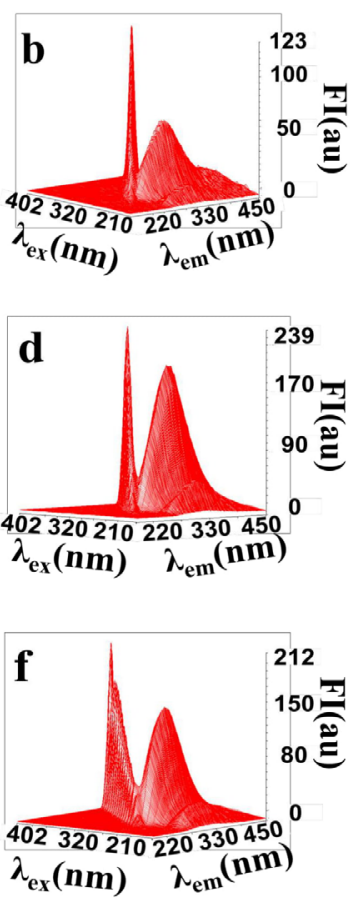

3D map surface
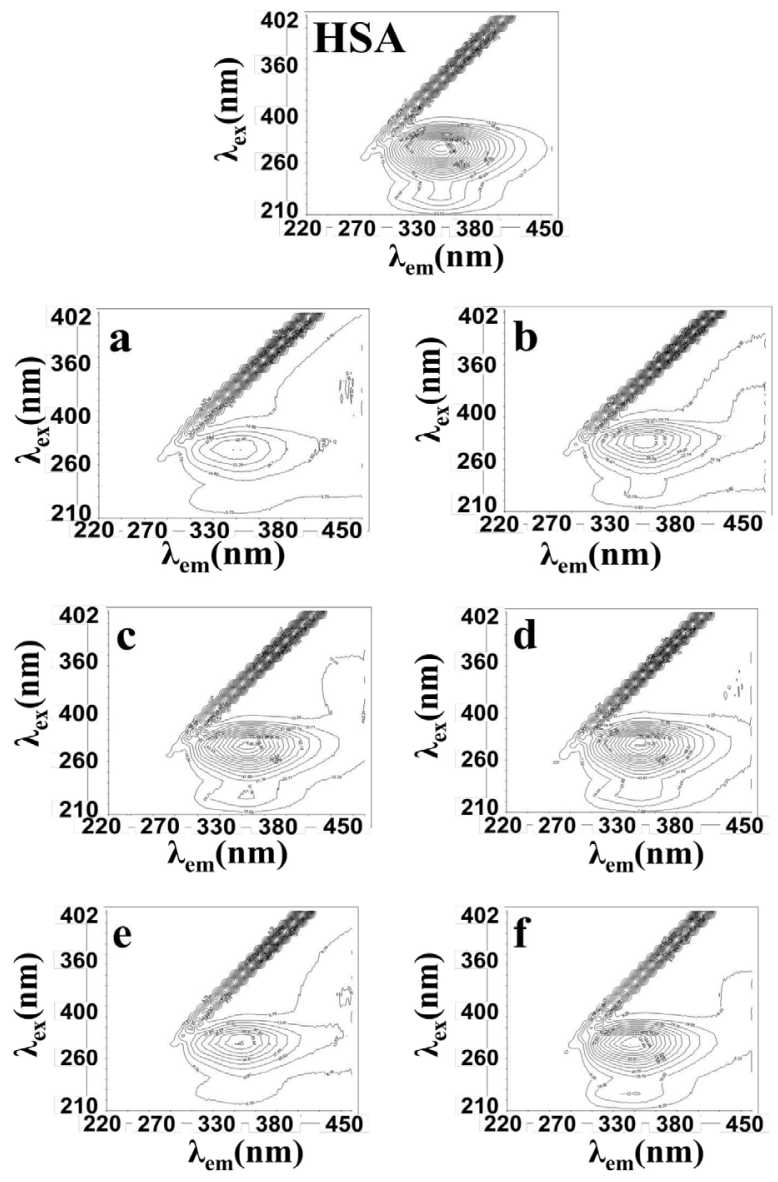

Figure 4. The three-dimensional fluorescence (3D-FL) and 3D map surface spectra of HSA and HSA + flavonoid systems. $5 \mu \mathrm{g} / \mathrm{mL} \mathrm{HF} 1+\mathrm{HSA}$ (a), $1.7 \mu \mathrm{g} / \mathrm{mL} \mathrm{HF2}+\mathrm{HSA}$ (b), $5 \mu \mathrm{g} / \mathrm{mL} \mathrm{HF3}+\mathrm{HSA}$ (c), $5 \mu \mathrm{g} / \mathrm{mL}$ HF4 + HSA (d) $5 \mu \mathrm{g} / \mathrm{mL}$ HF5 + HSA (e), $37.5 \mu \mathrm{g} / \mathrm{mL}$ HF6 + HSA (f). Human serum albumin (HSA), 7,5'-dimethoxyisoetin (HF1), homoorientin6"-4-O-methyl-myo-inositol (HF2), (2R,3R)-(+)-dihydrokaempferol-7,4'-dimethylether (HF3) and eriodictyol7,4'-dimethylether (HF4), isoorientin (HF5) and genkwanin (HF6). The 3D-FL and 3D map surface spectra of the flavonoid-HSA interactions were performed by the optimum experimental conditions: fluorescence intensity up to 270 , emission wavelengths from 220 to $450 \mathrm{~nm}$, excitation wavelengths from 210 to $450 \mathrm{~nm}$, scanning speed of $1000 \mathrm{~nm} / \mathrm{min}$ and emission slit spacing of $5 \mathrm{~nm}$.

$\mathrm{mL}$ ) according to the other compounds (Figure

3). The FIs in 3D-FL and 3D map surface spectra were measured as 137.4 and, $\lambda_{\text {ex }} / \lambda_{\text {em }}$ values for HF6 $(37.5 \mu \mathrm{g} / \mathrm{mL})+$ HSA system were 271/342 (Figure 4).

The binding constant $\left(K_{b}\right)$ values of the systems HSA-flavonoids (at different concentration ranges) were ranked by decreasing values as follows: $6.00 \times 10^{4} \mathrm{M}^{-1}(\mathrm{HF} 2)>3.81 \times 10^{4}$ $\mathrm{M}^{-1}(\mathrm{HF} 1)>2.47 \times 10^{4} \mathrm{M}^{-1}(\mathrm{HF} 5)>5.46 \times 10^{3} \mathrm{M}^{-1}(\mathrm{HF} 3)$
$>4.79 \times 10^{3} \mathrm{M}^{-1}$ (HF4) >6.30 × 10 $\mathrm{M}^{-1}$ (HF6) (Table I). The Stern-Volmer plot was obtained using the fluorescence intensity rates $\left(F_{0} / F\right)$ of the HSA in the absence/presence of the flavonoids and their concentrations [Q]. When the 2D-FL and 3D-FL studies in the flavonoid-HSA system were examined, the phenolic compounds containing polar functional group showed better interaction with the HSA (Hamid et al. 2017, Park et al. 2015). These result also demonstrated that the 
flavonoids containing the polar functional group in our study interact strongly with the HSA.

As previously mentioned HSA is the most abundant protein in blood plasma and is an important carrier for many pharmaceutical components such as flavonoids. The bioactivity of the flavonoids from plant-based natural products such as herbs, vegetables and fruits, affects blood and microvascular endothelial cells, and it is essential to detect the interaction between serum albumin of flavonoids (Liu et al. 2010).

Flavonoids the comprehensive biological activities and the use of this class of compounds as traditional medicine and dietary supplement is becoming increasingly common. Unfortunately, researches on the flavonoids are still limited to pharmacokinetic, bioavailability, biogenomy and safety due to the unique arrangement of hydroxylation, methoxylation, hydrogenation of the C2-C3 double bond and glycosylation in the aromatic ring structures. Therefore, flavonoids newly discovered from natural sources are structural changes of flavonoids affect the binding of these compounds to HSA. In literature, it was reported that the hydroxylation and methoxylation in the flavonoid skeleton increased the binding capacity of the flavonoids to HSA, whereas the glycosylation and hydrogenation of the C2-C3 double bond in structure decreased the binding capacity of HSA (Cao et al. 2019).

On the other hand, the exact amount of flavonoids to be taken with diet, which is one of the most important issues, is still unknown (Chen et al. 2017, 2018). Based on preclinical tests using in vitro bioactivity studies, the following can be expressed. Inhibition of cancer cell proliferation and interactions with macro biomolecules of flavonoids significantly affect the chemical structure of these compounds. However, these in vitro studies do not take into account the bioavailability and biotransformation of these compounds. Moreover, the doses and concentrations ( $>10 \mu \mathrm{M}$ ) of flavonoids used in these in vitro and in vivo preclinical studies may be difficult to obtain only from the diet of humans. Therefore, flavonoids may need to be consumed as nutraceuticals to obtain beneficial doses and further clinical studies are warranted to test the efficacy of complementary forms of flavonoids. Biological activity studies examining the effects of flavonoids often use very high concentrations that may not be physiologically relevant. Therefore, the benefits seen in in vitro bioactivity studies cannot be translated to in vivo. In clinical trials, further clinical research is warranted to investigate the bioavailability of dietary flavonoids and changes in serum biomarkers (Tapas et al. 2008, Jun et al. 2016, Millar et al. 2017, Kent et al. 2018). Some studies have shown that drugs that have a high capacity to bind to plasma proteins have usually longer half-life, are long-lasting, and run slowly in the plasma (Obach 1999, Pu et al. 2018). Therefore, the binding capacity of flavonoid to plasma proteins may be used as some rational indicators. Knowing the protein binding capacity of drug candidate molecules will enable us to obtain in-vivo activity and rational data for drug use. The binding capacity of a drug to a protein depends on the main factors such as stability, distribution, excretion, metabolism of the drug, complexing with other molecules and interaction with tissues (Xiao \& Kai 2012).

It is important to predict the molecular bioavailability of natural flavonoids to establish the relationship between binding capacity to plasma protein and cancer activities to provide reliable data for clinical application research. 
Table I. Binding constant $\left(K_{b}\right)$, number of attached moieties $(n)$ and Stern-Volmer values for flavonoid-HSA interactions.

\begin{tabular}{|c|c|c|c|c|c|c|c|}
\hline & \multicolumn{3}{|c|}{$\boldsymbol{K}_{b}$ and $\mathbf{n}$ values } & \multicolumn{3}{c|}{ Stern-Volmer values } \\
\hline Flavonoids & Equation & $\boldsymbol{K}_{b}\left(\mathbf{M}^{-1}\right)$ & $\mathbf{n}$ & $\mathbf{R}^{2}$ & Equation & $\boldsymbol{K}_{\text {sv }}\left(\mathbf{M}^{-1}\right)$ & $\mathbf{R}^{\mathbf{2}}$ \\
\hline HF1 & $\mathrm{y}=1.287 x-1.419$ & $3.81 \times 10^{4}$ & 1.287 & 0.927 & $\mathrm{y}=0.113 \mathrm{x}+1$ & 0.113 & 0.972 \\
\hline HF2 & $\mathrm{y}=1.630 \mathrm{x}-1.222$ & $6.00 \times 10^{4}$ & 1.630 & 0.861 & $\mathrm{y}=0.341 \mathrm{x}+1$ & 0.341 & 0.893 \\
\hline HF3 & $\mathrm{y}=1.691 \mathrm{x}-2.263$ & $5.46 \times 10^{3}$ & 1.691 & 0.968 & $\mathrm{y}=0.079 \mathrm{x}+1$ & 0.079 & 0.903 \\
\hline HF4 & $\mathrm{y}=1.943 \mathrm{x}-2.319$ & $4.79 \times 10^{3}$ & 1.943 & 0.962 & $\mathrm{y}=0.169 \mathrm{x}+1$ & 0.169 & 0.726 \\
\hline HF5 & $\mathrm{y}=1.192 \mathrm{x}-1.607$ & $2.47 \times 10^{4}$ & 1.192 & 0.708 & $\mathrm{y}=0.051 \mathrm{x}+1$ & 0.051 & 0.912 \\
\hline HF6 & $\mathrm{y}=1.545 \mathrm{x}-3.196$ & $6.30 \times 10^{2}$ & 1.545 & 0.949 & $\mathrm{y}=0.015 \mathrm{x}+1$ & 0.015 & 0.973 \\
\hline
\end{tabular}

\section{CONCLUSIONS}

For novel uses of herbal-flavonoids, antiproliferative activities and HSA binding capacities were investigated. HF3 and HF5 showed the strongest anti-proliferative effect against HeLa and PC3 cell lines, respectively. The HF1 and HF2 showed a strong interaction with the blood plasma protein HSA. Although glycosidic and aglycone forms of flavonoids are very common, flavonoids containing a group of inositol such as the compound HF2 are scarce in the literature. Therefore, considering the development of new drugs, it is crucial to check newly isolated natural product related compounds for their activities in different in vitro assays. Effective new bioactive compounds from natural sources are considered to be the basis of pre-clinical studies, especially in the fields of medicine, pharmacological and biomedical applications. In addition, semisynthetic derivatives of target flavonoids are becoming increasingly widespread in the pharmaceutical industry, especially in food, cosmetics, medicinal, pharmaceutical and phytotherapeutic. Thus, novel semi-synthetic derivatives can be obtained to create new areas. For the tested flavonoids, those with high HSA binding affinities can be tested for their further bioavailability by in vitro biological activity parameters such as antioxidant, antimicrobial, anti-diabetic and anti-Alzheimer activities. Apoptosis and telomerase activities can be investigated at the molecular level using structure-activity relations.

\section{Acknowledgments}

The authors would like thanks to the Scientific and Technological Research Council of Turkey (TUBITAK) and Scientific Research Projects Department of Bingöl University (BUBAP) that supported this work with project number $115 Z 088$ and BAP-21-322-2015, respectively. The author would like to thank Dr. Muhammed Altun for antiproliferative activity studies and Serkan Koldaş for the grammatical revisions, and Assoc. Dr. Mahmut Toprak for their help in HSA studies.

\section{REFERENCES}

ABAY G, ALTUN M, KOLDAS S, TUFEKCI AR \& DEMIRTAS I. 2015. Determination of antiproliferative activities of volatile contents and HPLC profiles of Dicranum scoparium (Dicranaceae, Bryophyta). Comb Chem High T Scr 18(5): 453-463.

AWOUAFACKMD, AIMAITIS, TANE P, MORITA H \& CLERODENDRUMOL A. 2016. New Triterpenoid from Clerodendrum yaundense Gürke (Lamiaceae). Helv Chim Acta 99(2): 161-164.

BADR JM, IBRAHIM SR \& ABOU-HUSSEIN DR. 2016. Plicosepalin $A$, a new antioxidant catechin-gallic acid derivative of inositol from the mistletoe Plicosepalus curviflorus. Z Naturforsc 71(11-12): 375-380.

BAHMANI M, SHIRZAD H, SHAHINFARD N, SHEIVANDI L \& RAFIEIANKOPAEI M. 2017. Cancer phytotherapy: Recent views on the role of antioxidant and angiogenesis activities. J EvidBased Complement Alternat Med 22(2): 299-309. 
BANDGAR BP, GAWANDE SS, BODADE RG, TOTRE JV \& KHOBRAGADE CN. 2010. Synthesis and biological evaluation of simple methoxylated chalcones as anticancer, antiinflammatory and antioxidant agents. Bioorg Med Chem 18(3): 1364-1370.

BASKEN NE \& GREEN MA. 2009. Cu (II) bis (thiosemicarbazone) radiopharmaceutical binding to serum albumin: further definition of species dependence and associated substituent effects. Nucl Med Biol 36(5): 495-504.

BEKING K \& VIEIRA A. 2010. Flavonoid intake and disabilityadjusted life years due to Alzheimer's and related dementias: a population-based study involving twentythree developed countries. Public Health Nutr 13(9): 1403-1409.

BIAN Q, LIU J, TIAN J \& HU Z. 2004. Binding of genistein to human serum albumin demonstrated using tryptophan fluorescence quenching. Int J Biol Macromol 34(5): 275-279.

BIJAK M, SUT A, KOSIOREK A, SALUK-BIJAK J \& GOLANSKI J. 2019. Dual Anticoagulant/Antiplatelet Activity of Polyphenolic Grape Seeds Extract. Nutrients 11(1): 93.

BOLLI A, MARINO M, RIMBACH G, FANALI G, FASANO M \& ASCENZI P. 2010. Flavonoid binding to human serum albumin. Biochem Bioph Res Co 398(3): 444-449.

BOUBAKEUR B, TIRTOUIL A, MEDDAH B \& KHADEM H. 2015. The evaluation of the effect of synthetic flavonoids on growth of pathogenic and probiotic bacteria. J Chem Pharm Res 7(10): 228-236.

CALLMANN CE ET AL. 2019. Antitumor Activity of 1, 18-Octadecanedioic Acid-Paclitaxel Complexed with Human Serum Albumin. J Am Chem Soc 141(30): 11765-11769.

CAO H, LIU X, ULRIH NP, SENGUPTA PK \& XIAO J. 2019. Plasma protein binding of dietary polyphenols to human serum albumin: A high performance affinity chromatography approach. Food Chem 270: 257-263.

CASTELL MJ, PEREZ-CANO F, ABRIL-GIL M \& FRANCH A. 2014. Flavonoids on allergy. Current Pharm Design 20(6): 973-987.

CHEN L, TENG H, JIA Z, BATTINO M, MIRON A, YU Z \& XIAO J. 2017. Intracellular signaling pathways of inflammation modulated by dietary flavonoids: The most recent evidence. Crit Rev Food Sci Nutr 58(17): 2908-2924.

CHEN L, TENG H, XIE Z, CAO H, CHEANG WS, SKALICKA-WONIAK K \& XIAO J. 2018. Modifications of dietary flavonoids towards improved bioactivity: an update on structure-activity relationship. Crit Rev Food Sci Nutr 58(4): 513-527.
CHOI EJ, LEE JI \& KIM GH. 2012. Evaluation of the anticancer activities of thioflavanone and thioflavone in human breast cancer cell lines. Int J Mol Med 29(2): 252-256.

CUI FL, YAN YH, ZHANG QZ, QU GR, DU J \& YAO XJ. 2010. A study on the interaction between 5-Methyluridine and human serum albumin using fluorescence quenching method and molecular modeling. J Mol Model 16(2): 255-262.

DAS M, MANNA K, BANIK U, GHOSH PS \& SARKAR P. 2014. Biologically potential flavones: A subgroup of flavonoids. Int J Pharm Sci Res 5: 3840-3848.

DEMIRTAS I, GECIBESLER IH \& YAGLIOGLU AS. 2013. Antiproliferative activities of isolated flavone glycosides and fatty acids from Stachysbyzantina. Phytochem Lett 6(2): 209-214.

DIBARI L, RIPOLIS, PRADHAN S \& SALVADORIP. 2010. Interactions between quercetin and warfarin for albumin binding: a new eye on food/drug interference. Chirality 22(6): 593-596.

DU Q \& CHEN H. 2010. The methoxyflavones in Citrus reticulata Blanco $\mathrm{CV}$. ponkan and their antiproliferative activity against cancer cells. Food Chem 119(2): 567-572.

ERDOGAN S, DOGANLAR O, DOGANLAR ZB, SERTTAS R, TURKEKUL K, DIBIRDIK I \& BILIR A. 2016. The flavonoid apigenin reduces prostate cancer CD44+ stem cell survival and migration through PI3K/Akt/NF-kBsignaling. Life Sci 162: 77-86.

FAGGIO C, SUREDA A, MORABITO S, SANCHES-SILVA A, MOCAN A, NABAVI SF \& NABAVI SM. 2017. Flavonoids and platelet aggregation: a brief review. Eur J Pharmacol 807: 91-101.

GECIBESLER IH. 2019. Antioxidant activity and phenolic profileof Turkish Celtis tournefortii. Chem Nat Compd 55(4): 738-742

GECIBESLER IH, DEMIRTAS I, BEHCET L \& TUFEKCI AR. 2017. TwO new flavonoids and other phytochemicals from endemic Phryna ortegioides (Fish. \& CA Mey.) Pax \& K. Hoffm and their antioxidant potentials. Rec Nat Prod 11(3): 290-298.

GECIBESLER IH \& ERDOGAN M. 2019. A new nutraceutical resource from a rare native plant growing in Turkey and for its spectro-chemical and biological insights: Endemic Diplotaenia bingolensis (Apiaceae). Spectrochim Acta A 223: 117358.

GECIBESLER IH, KOCAK A \& DEMIRTAS I. 2016. Biological activities, phenolic profiles and essential oil components of Tanacetum cilicicum (Boiss.) Grierson. Nat Prod Res 30(24): 2850-2855.

GECIBESLER IH, YAGLIOGLU AS, GUL F, TEMIRTURK M \& DEMIRTAS I. 2019. Phytochemicals of Chrysophthalmum montanum (DC.) Boiss. roots and their antiproliferative activities 
against HeLa and C6 cell lines. Proc Nati Acad Sci India Sec B: Bio Sci 89(1): 145-154.

GRIGALIUS I \& PETRIKAITE V. 2017. Relationship between antioxidant and anticancer activity of trihydroxyflavones. Molecules 22(12): 2169.

GUGLIELMONE HA, AGNESE AM, MONTOYA SCN \& CABRERA JL. 2002. Anticoagulant effect and action mechanism of sulphated flavonoids from Flaveria bidentis. Thromb Res 105(2): 183-188.

HAMID NAA, MEDIANI A, MAULIDIANI M, ABAS F, PARK YS, LEONTOWICZ H \& GORINSTEIN S. 2017. Characterization of metabolites in different kiwifruit varieties by NMR and fluorescence spectroscopy. J Pharmaceut Biomed 138: 80-91.

HAVSTEEN BH. 2002. The biochemistry and medical significance of the flavonoids. Pharmacol Therapeut 96(2-3): 67-202.

JUN S, SHIN S \& JOUNG H. 2016. Estimation of dietary flavonoid intake and major food sources of Korean adults. Br J Nutr 115(3): 480-489.

KANADASWAMI C, LEE LT, LEE PPH, HWANG JJ, KE FC, HUANG YT \& LEE MT. 2005. The antitumor activities of flavonoids. In vivo 19(5): 895-909.

KANAKIS CD, TARANTILIS PA, POLISSIOU MG, DIAMANTOGLOU S \& TAJMIR-RIAHI HA. 2006. Antioxidant flavonoids bind human serum albumin. J Mol Struct 798(1-3): 69-74.

KARAKAYA L, AKGUL Y \& NALBANTSOY A. 2017. Chemical constituents and in vitro biological activities of Eremurus spectabilis leaves. Nat Prod Res 31(15): 1786-1791.

KAWAII S, TOMONO Y, KATASE E, OGAWA K \& YANO M. 1999. Antiproliferative activity of flavonoids on several cancer cell lines. Biosci Biotechnol Biochem 63(5): 896-899.

KENT K, CHARLTON KE, LEE S, MOND J, RUSSELL J, MITCHELL P \& FLOOD VM. 2018. Dietary flavonoid intake in older adults: how many days of dietary assessment are required and what is the impact of seasonality? Nutr J 17(1): 7.

KHAN H, JAWAD M, KAMAL MA, BALDI A, XIAO J, NABAVI SM \& DAGLIA M. 2018. Evidence and prospective of plant derived flavonoids as antiplatelet agents: Strong candidates to be drugs of future. Food Chemical Toxicol 119: 355-367.

KILANI-JAZIRI S, FRACHET V, BHOURI W, GHEDIRA K, CHEKIRGHEDIRA L \& RONOT X. 2012. Flavones inhibit the proliferation of human tumor cancer cell lines by inducing apoptosis. Drug Chem Toxico 35(1): 1-10.

LIS, LO CY \& HO CT. 2006. Hydroxylated polymethoxyflavones and methylated flavonoids in sweet orange (Citrus sinensis) peel. J Agric Food Chem 54(12): 4176-4185.
LI S, PAN MH, LAI CS, LO CY, DUSHENKOV S \& HO CT. 2007. Isolation and syntheses of polymethoxyflavones and hydroxylated polymethoxyflavones as inhibitors of $\mathrm{HL}$ 60 cell lines. Bioorg Med Chem 15(10): 3381-3389.

LIN D, KUANG G, WAN J, ZHANG X, LI H, GONG X \& LI H. 2017. Luteolin suppresses the metastasis of triple-negative breast cancer by reversing epithelial-to-mesenchymal transition via downregulation of $\beta$-catenin expression. Oncol Rep 37(2): 895-902.

LIU BM, ZHANG J, BAI CL, WANG X, QIU XZ, WANG XL, JI H \& LIU B. 2015. Spectroscopic study on flavonoid-drug interactions: competitive binding for human serum albumin between three flavonoid compounds and ticagrelor, a new antiplatelet drug. J Lumin 168: 69-76.

LIU EH, QI LW \& LI P. 2010. Structural relationship and binding mechanisms of five flavonoids with bovine serum albumin. Molecules 15(12): 9092-9103.

MARTENS S \& MITHÖFER A. 2005. Flavones and flavone synthases. Phytochemistry 66(20): 2399-2407.

MARZOCCHELLA L, FANTINI M, BENVENUTO M, MASUELLI L, TRESOLDI I, MODESTI A \& BEI R. 2011. Dietary flavonoids: molecular mechanisms of action as anti-inflammatory agents. Recent Pat Inflamm Allergy Drug Discov 5(3): 200-220.

MENEZES JC, ORLIKOVA B, MORCEAU F \& DIEDERICH M. 2016. Natural and synthetic flavonoids: structure-activity relationship and chemotherapeutic potential for the treatment of leukemia. Crit Rev Food Sci Nutr 56(suppl1): S4-S28.

MILLAR CL, DUCLOS Q \& BLESSO CN. 2017. Effects of dietary flavonoids on reverse cholesterol transport, HDL metabolism, and HDL function. Adv Nutr 8(2): 226-239.

MOHAN V, SENGUPTA B, ACHARYYA A, YADAV R, DAS N \& SEN P. 2018. Region-specific double denaturation of human serum albumin: combined effects of temperature and $\mathrm{GnHCl}$ on structural and dynamical responses. ACS Omega 3(8): 10406-10417.

NAIK PN, CHIMATADAR SA \& NANDIBEWOOR ST. 2010. Interaction between a potent corticosteroid drugdexamethasone with bovine serum albumin and human serum albumin: a fluorescence quenching and fourier transformation infrared spectroscopy study. J Photoch Photobio B 100(3): 147-159.

NAMIESNIK J, VEARASILP K, NEMIROVSKI A, LEONTOWICZ H, LEONTOWICZ M, PASKO P \& GORINSTEIN S. 2014. In vitro studies on the relationship between the antioxidant activities of some berry extracts and their binding properties to serum albumin. Appl Biochem Biotech 172(6): 2849-2865. 
NARAZAKI R, MARUYAMA T \& OTAGIRI M. 1997. Probing the cysteine 34 residue in human serum albumin using fluorescence techniques. BBA-Protein Struct M 1338(2): 275-281.

OBACH RS. 1999. Prediction of human clearance of twentynine drugs from hepatic microsomal intrinsic clearance data: an examination of in vitro half-life approach and nonspecific binding to microsomes. Drug Metab Dispos 27(11): 1350-1359.

OKE ALTUNTAS F, DEMIRTAS I, TUFEKCI AR, KOLDAS S, GUL F, BEHCET L \& GECIBESLER HI. 2016. Inhibitory effects of the active components isolated from Satureja Boissieri Hausskn. Ex Boiss. On human cervical cancer cell line. J Food Biochem 40(4): 499-506.

PAL D \& VERMA P. 2013. Flavonoids: A powerful and abundant source of antioxidants. Int J Pharm Pharm Sci 5(3): 95-98.

PANG X ET AL. 2019. Human serum albumin nanoparticulate system with encapsulation of gefitinib for enhanced anti-tumor effects in non-small cell lung cancer. J Drug Deliv Sci Tec 52: 997-1007.

PARK YS, POLOVKA M, MARTINEZ-AYALA AL, GONZALEZ-AGUILAR GA, HAM KS, KANG SG \& GORINSTEIN S. 2015. Fluorescence studies by quenching and protein unfolding on the interaction of bioactive compounds in water extracts of kiwi fruit cultivars with human serum albumin. J Lumin 160: 71-77.

PATHAK N, KHAN S, BHARGAVA A, RAGHURAM GV, JAIN D, PANWAR H \& MISHRA PK. 2014. Cancer chemopreventive effects of the flavonoid-rich fraction isolated from papaya seeds. Nutr Cancer 66(5): 857-871.

PAWAR S, TANDEL R, KUNABEVU R \& JALDAPPAGARI S. 2019. Spectroscopic and computational approaches to unravel the mode of binding between aisoflavone, biochanin-A and calf thymus DNA. J Biomol Struct Dyn 37(4): 846-856.

PINHEIRO PF \& JUSTINO GC. 2012. Structural analysis of flavonoids and related compounds-A review of spectroscopic applications. In: Venketeshwer R (Ed), Phytochemicals a global perspective of their role in nutrition and health, InTech, Morn Hill, UK, p. 33-56.

POOR M, KUNSAGI-MATE S, BENCSIK T, PETRIK J, VLADIMIRKNEZEVIC S \& KOSZEGI T. 2012. Flavonoid aglycones can compete with Ochratoxin A for human serum albumin: A new possible mode of action. Int J Biol Macro 51(3): 279-283.

POUGET C, LAUTHIER F, SIMON A, FAGNERE C, BASLY JP, DELAGE C \& CHULIA AJ. 2001. Flavonoids: structural requirements for antiproliferative activity on breast cancer cells. Bioorg Med Chem Lett 11(24): 3095-3097.

PU J, WANG F, TANG W \& ZHU M. 2018. Biotransformation of ilaprazole in human liver microsomes and human: role of CYP3A4 in ilaprazole clearance and drug-drug interaction. Drug Metab Dispos 46(10): 1453-1461.

RAHA S, YUMNAM S, HONG GE, LEE HJ, SARALAMMA VVG, PARK HS \& KIM GS. 2015. Naringin induces autophagy-mediated growth inhibition by downregulating the PI3K/Akt/mTOR cascade via activation of MAPK pathways in AGS cancer cells. Int J Oncol 47(3): 1061-1069.

RIMAC H, DUFOUR C, DEBELJAK Z, ZORC B \& BOJIC M. 2017. Warfarin and flavonoids do not share the same binding region in binding to the IIA subdomain of human serum albumin. Molecules 22(7): 1153.

SALCI A \& TOPRAK M. 2017. Spectroscopic investigations on the binding of Pyronin $Y$ to human serum albumin. J Biomol Struct Dyn 35(1): 8-16.

SEITO LN, RUIZ ALTG, VENDRAMINI-COSTA D, TINTI SV, DE CARVALHO JE, BASTOS JK \& DI STASI LC. 2011. Antiproliferative activity of three methoxylated flavonoids isolated from Zeyheria montana Mart. (Bignoniaceae) leaves. Phytother Res 25(10): 1447-1450.

SEN P, FATIMA S, AHMAD B \& KHAN RH. 2009. Interactions of thioflavin $T$ with serum albumins: spectroscopic analyses. Spectrochim Acta A Mol Biomol Spectrosc 74(1): 94-99.

TAPAS AR, SAKARKAR DM \& KAKDE RB. 2008. Flavonoids as nutraceuticals: a review. Trop J Pharm Res 7(3): 1089-1099.

TERAO J. 2017. Factors modulating bioavailability of quercetin-related flavonoids and the consequences of their vascular function. Biochem Pharmacol 139: 15-23.

TOMINAGA Y, MAE T, KITANO M, SAKAMOTO Y, IKEMATSU H \& NAKAGAWA K. 2006. Licorice flavonoid oil effects body weight loss by reduction of body fat mass in overweight subjects. J Health Sci 52(6): 672-683.

TRISCHITTA F \& FAGGIO C. 2006. Effect of the flavonol quercetin on ion transport in the isolated intestine of the eel, Anguilla anguilla. Comp Biochem Physiol C Toxicol Pharmacol 143(1): 17-22.

VANEKOVA Z, HUBCIK L, TOCA-HERRERA JL, FURTMULLER PG, VALENTOVA J, MUCAJI P \& NAGY M. 2019. Study of interactions between amlodipine and quercetin on human serum albumin: Spectroscopic and modelling approaches. Molecules 24(3): 487. 
WALLE T. 2007. Methylation of dietary flavones greatly improves their hepatic metabolic stability and intestinal absorption. Mol Pharm 4(6): 826-832.

WALLE T, TA N, KAWAMORI T, WEN X, TSUJI PA \& WALLE UK. 2007. Cancer chemopreventive properties of orally bioavailable flavonoids-methylated versus unmethylated flavones. Biochem Pharmacol 73(9): 1288-1296.

WANG B, QIN Q, CHANG M, LI S, SHI X \& XU G. 2018. Molecular interaction study of flavonoids with human serum albumin using native mass spectrometry and molecular modeling. Anal Bioanal Chem 410(3): 827-837.

WANG X, OUYANG YY, LIU J \& ZHAO G. 2014. Flavonoid intake and risk of CVD: a systematic review and meta-analysis of prospective cohort studies. Brit J Nutr 111(1): 1-11.

WANG YQ, ZHANG HM \& ZHANG GC. 2006. Studies of the interaction between palmatine hydrochloride and human serum albumin by fluorescence quenching method. J Pharm Biomed 41(3): 1041-1046.

WONGSRIKAEW N, KIM H, VICHITPHAN K, CHO SK \& HAN J. 2012. Antiproliferative activity and polymethoxyflavone composition analysis of Kaempferia parviflora extracts. J Korean Soc Applied Bi 55(6): 813-817.

WONGSRIKAEW N, WOO HC, VICHITPHAN K \& HAN J. 2011. Supercritical $\mathrm{CO}_{2}$ for efficient extraction of polymethoxyflavones in Kaempferia parviflora. J Korean Soc Applied Bi 54(6): 1008-1011.

WOO HD \& KIM J. 2013. Dietary flavonoid intake and smoking-related cancer risk: a meta-analysis. PLOS ONE 8(9): e75604.

XIAO J \& KAi GA. 2012. Review of dietary polyphenol-plasma protein interactions: characterization, influence on the bioactivity, and structure-affinity relationship. Crit Rev Food Sci Nutr 52(1): 85-101.

YASEEN Z, ASWAL VK, ZHOU X \& HAIDER S. 2018. Morphological changes in human serum albumin in the presence of cationic amphiphilic drugs. New J Chem 42(3): 2270-2277.

ZENG L, ZHEN Y, CHEN Y, ZOU L, ZHANG Y, HU F \& WEI B. 2014. Naringin inhibits growth and induces apoptosis by a mechanism dependent on reduced activation of NFKB/ COX2caspase-1 pathway in HeLa cervical cancer cells. Int J Oncol 45(5): 1929-1936.

\section{How to cite}

GECIBESLER IH \& AYDIN M. 2020. Plasma Protein Binding of HerbalFlavonoids to Human Serum Albumin and Their Anti-proliferative Activities. An Acad Bras Cienc 92: e20190819. DOI 10.1590/00013765202020190819.
Manuscript received on July 17, 2019;

accepted for publication on October 23, 2019

\section{IBRAHIM HALIL GECIBESLER ${ }^{1}$}

https://orcid.org/0000-0002-4473-2671

\section{MURAT AYDIN ${ }^{2}$}

https://orcid.org/0000-0002-4672-232X

${ }^{1}$ Bingol University, Faculty of Health Sciences, Department of Occupational Health and Safety, Laboratory of Natural Product Research, 12000, Bingol, Turkey

${ }^{2}$ Bingol University, Faculty of Science and Art, Department of Chemistry, 12000, Bingol, Turkey

Correspondence to: Ibrahim Halil Gecibesler E-mails: igecibesler@bingol.edu.tr; ibrahimgecibesler@gmail.com

\section{Author contributions}

Ibrahim Halil Gecibesler contributed to the study by conducting the study, experimental design, project design and data analysis. Murat Aydin has contributed to experimental and laboratory studies.

\section{(cc) BY}

